\title{
FREE AND BOUND PHENOLIC ACIDS IN INFLORESCENCES AND RHIZOMES WITH ROOTS OF HIERACIUM PILOSELLA L. (ASTERACEAE)
}

\author{
MoniKa GawrońsKa-GrZYwacz, TADEUSZ KRZACZEK \\ Department of Pharmaceutical Botany of the Medical University of Lublin \\ Chodźki 1, 20-093 Lublin, Poland \\ e-mail: tadeusz.krzaczek@am.lublin.pl
}

(Received: December 6, 2005. Accepted: March 20, 2006)

\begin{abstract}
The analysis of the fractions of free and bound, liberated by hydrolysis, phenolic acids in the inflorescences and rhizomes with roots of Hieracium pilosella L. was conducted by 2D-TLC and RP-HPLC methods. In the inflorescences fourteen phenolic acids were found: chlorogenic, gallic, protocatechuic, homoprotocatechuic, caffeic, gentisic, p-hydroxyphenylacetic, p-hydroxybenzoic, m-hydroxybenzoic, p-coumaric, syringic, vanillic, ferulic and salicylic. In the rhizomes with roots nine phenolic acids were identified: chlorogenic, gallic, homoprotocatechuic, caffeic, gentisic, p- hydroxyphenylacetic, p-hydroxybenzoic, syringic and vanillic. By means of the RPHPLC method the contents of major acids were estimated which ranged from $0.01 \mathrm{mg} \%$ up to $139.50 \mathrm{mg} \%$. Caffeic acid is the remarkably dominating constituent of both plant materials. Phenolic compounds may contribute to invasiveness and medicinal properties of this species.
\end{abstract}

KEY WORDS: Hieracium pilosella L., phenolic acids, SPE, 2D-TLC, RP-HPLC.

\section{INTRODUCTION}

Hieracium pilosella $\mathrm{L}$. (mouse-ear hawkweed) is a common plant and a very invasive weed native to Eurasia, but it has been introduced into North America and into New Zealand.

Especially in that last country $H$. pilosella became a serious problem because having few natural predators or diseases it spreads there in overgrazed, nutrient-poor pastures and displaces indigenous species. This plant is able to tolerate an appreciably low soil-water content and its rosette leaves and rhizomes enable it to form thick patches. These features share the responsibility for its invasiveness. Besides the morphology and physiology, the biochemistry of this plant plays a significant role in this phenomenon. It was proved that phenolics have strong alleopathic potential and are exuded to the environment by some plants. These compounds suppress the growth of neighbouring species (Kopcewicz 1998). Phenolic acids are also well-known inhibitors of seed germination and interact synergistically to enhance the inhibitory effect (Harborne 1997). Hieracium pilosella contains many phenolic compounds with phytotoxic properties and chlorogenic acid and caffeic acid (also umbelliferone) are the most important among them (Bishop and Davy 1994).

On the other hand mouse-ear hawkweed is well-known for its therapeutic activity. It was used in ethnomedicine for ages not only in Europe but also in so far-away countries like Iran or Lebanon (Miraldi et al. 2001; Barbour et al. 2004). Phenolic acids may be responsible for antiseptic and expectorant effects of the extracts from mouse-ear hawkweed (Bown 1999; Broda and Mowszowicz 2000; Kuźniewski and Augustyn-Puziewicz 1984).

So far Dombrowicz et al. (1992) have determined the composition of phenolic acids in the herb of $H$. pilosella by GC method and Zidorn et al. (2002) have identified three depsids in its inflorescences: chlorogenic acid (5-caffeoylquinic acid), 3.5-dicaffeoylquinic acid and 4.5-dicaffeoylquinic acid. In the roots of $H$. pilosella Makepeace et al. (1985) have identified caffeic and chlorogenic acids. For the aforementioned reasons it seems to be legitimate to investigate the composition of all phenolic acids in the inflorescences and the roots and rhizomes of mouse-ear hawkweed.

The aim of the study was the identification of the phenolic acids in the inflorescences and the rhizomes with roots from Hieracium pilosella $\mathrm{L}$.

\section{MATERIAL AND METHODS}

\section{Plant material}

The plant material for research were the inflorescences and the rhizomes with roots of Hieracium pilosella $\mathrm{L}$. col- 
lected in Ćmiłów near Lublin. It was dried in normal conditions and adequately fragmented according to Polish Pharmacopoeia V. $50 \mathrm{~g}$ samples of the inflorescences and the rhizomes with roots were used in the study.

\section{Extraction and isolation}

The dried plant materials were extracted twice with boiling $80 \%$ methanol and then once with $60 \%$ boiling methanol. After evaporation of the solvents, the residues were eluted with hot water portions and after $24 \mathrm{~h}$ the aqueous extracts were filtered. Then, phenolic acids were isolated in a typical way for this group of compounds (Krzaczek 1984; Świątek and Dombrowicz 1984). Fractions of free phenolic acids (A) were isolated according to Ibrachim and Towers' method (1960).

The process of acidic hydrolysis of bound phenolic acids was performed according to Schmidtlein and Herrmann (1975) and Świątek and Dombrowicz (1984). The alkaline hydrolyses were performed with $\mathrm{Ba}(\mathrm{OH})_{2}$ in a reductive medium containing $\mathrm{NaBH}_{4}$ (Schmidtlein and Herrmann 1975). The obtained fractions of free phenolic acids (A) and bound phenolic acids liberated by both, first alkaline and next acidic hydrolysis (B), were dissolved in methanol.

The fractions of chlorogenic acid were obtained by extracting the aqueous layer with ethyl acetate and further procedure was the same but ethyl acetate, not diethyl ether, was used for extractions. The obtained fractions $\mathrm{C}$ were dissolved in methanol.

\section{SPE procedure}

The samples of fractions A-C were diluted with bidistilled water to make $70 \%$ solution of methanol in water. Octadecyl BakerBond SPE-micro-columns (1000 mg; J.T. Baker, Phillipsburg, NJ, USA) were first conditioned with $10 \mathrm{ml}$ methanol, $10 \mathrm{ml}$ bidistilled water and $10 \mathrm{ml} 70 \%$ aqueous methanol in turn. After that the samples were applied and the eluates containing phenolic acids were collected. In the next step, the columns were bathed with $5 \mathrm{ml}$ methanol which was combined with the eluates. The obtained samples containing the mixture of phenolic acids were evaporated to dryness and dissolved in methanol. The purified in this way fractions A, B, C were analyzed by $2 \mathrm{D}$ -TLC and RP-HPLC methods.

\section{Qualitative chromatography (2D-TLC)}

Two-dimensional thin layer chromatography (2D-TLC) was performed on $100 \times 100 \times 0.1 \mathrm{~mm}$ cellulose plates (Merck, Darmstadt). The chromatograms were developed "face down" in DS horizontal chamber (Dzido 1993) in the following mobile phases (Smolarz and Waksmundzka-Hajnos 1993):

\section{I direction:}

benzene - methanol - acetic acid - acetonitryle

$(80: 10: 5: 5 \mathrm{v} / \mathrm{v} / \mathrm{v} / \mathrm{v})$,

\section{II direction:}

sodium formate - formic acid - water (10:1:200 w/v/v).

To avoid eluent demixion, the plates were conditioned for about 5 minutes above vapours of benzene - methanol - acetic acid (90:5:5 v/v/v) and then developed in the first direction.

The chromatograms were observed in ultraviolet light at $366 \mathrm{~nm}$ before and after exposure to ammonia vapours. Then, visualization by derivatisation was performed by spraying the plates with one of the following reagents:

1) diazotized sulphanilic acid in $20 \%$ sodium carbonate solution (Linskens 1959);

2) diazotized p-nitroaniline in $10 \%$ sodium carbonate solution (Jerzmanowska 1967);

3) $2 \%$ aqueous solution of ferric chloride (Randerath 1959).

After derivatisation the chromatograms were observed in daylight. The phenolic acids were identified on the basis of comparison of analyzed compounds with authentic standards.

The obtained results of 2D-TLC analyses are shown in Table 1 and Figure 1.

TABLE 1. The occurrence of phenolic acids in Hieracium pilosella $\mathrm{L}$.

\begin{tabular}{|c|c|c|c|c|c|c|c|}
\hline \multirow{2}{*}{ No. } & \multirow[b]{2}{*}{ Phenolic acids } & \multicolumn{3}{|c|}{ Inflorescences } & \multicolumn{3}{|c|}{ Rhizomes with roots } \\
\hline & & $\begin{array}{l}\text { Free } \\
\text { (A) }\end{array}$ & $\begin{array}{l}\text { Bound } \\
\text { (B) }\end{array}$ & $\begin{array}{l}\text { Chlorogenic acid } \\
\text { (C) }\end{array}$ & $\begin{array}{l}\text { Free } \\
\text { (A) }\end{array}$ & $\begin{array}{l}\text { Bound } \\
\text { (B) }\end{array}$ & $\begin{array}{c}\text { Chlorogenic acid } \\
\text { (C) }\end{array}$ \\
\hline 1. & chlorogenic & - & - & + & - & - & + \\
\hline 2. & gallic & + & + & - & + & + & - \\
\hline 3. & protocatechuic & + & + & - & - & - & - \\
\hline 4. & homoprotocatechuic & + & + & - & - & + & - \\
\hline 5. & caffeic (trans + cis) & + & + & - & + & + & - \\
\hline 6. & gentisic & + & + & - & + & + & - \\
\hline 7. & p-hydroxyphenylacetic & + & + & - & + & + & - \\
\hline 8. & p-hydroxybenzoic & + & + & - & + & + & - \\
\hline 9. & m-hydroxybenzoic & - & + & - & - & - & - \\
\hline 10. & p-coumaric & + & + & - & - & - & - \\
\hline 11. & syringic & + & + & - & + & + & - \\
\hline 12. & vanillic & + & + & - & + & + & - \\
\hline 13. & ferulic (trans + cis $)$ & + & + & - & - & - & - \\
\hline 14. & salicylic & + & + & - & - & - & - \\
\hline
\end{tabular}




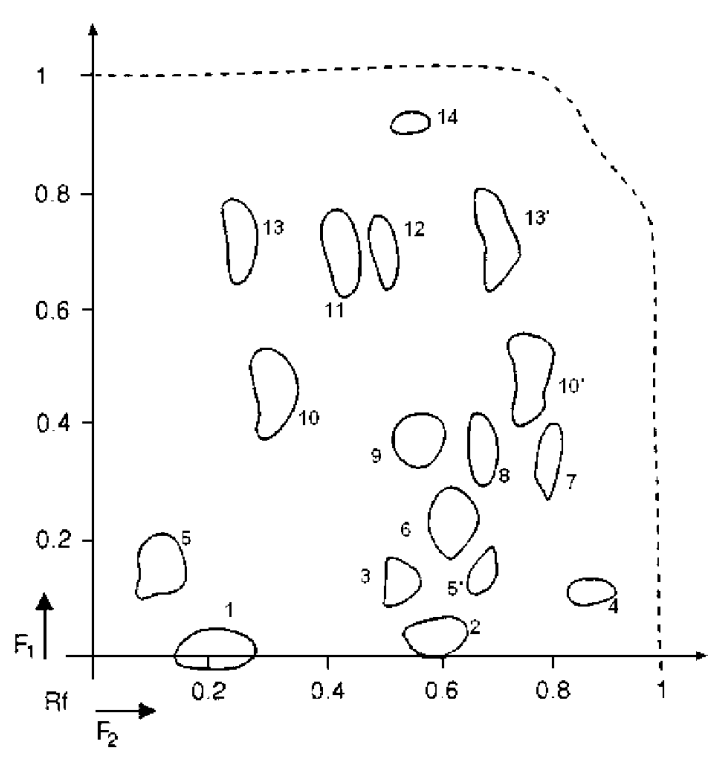

Fig. 1. The 2D-TLC chromatogram of phenolic acids from Hieracium pilosella. The identification numbers of spots refer to compounds listed in Table 1. The cis isomers are marked with an apostrophe.

\section{Semi-quantitative chromatography (RP-HPLC)}

The RP-HPLC analysis was performed using Knauer (Germany) liquid chromatograph equipped with a K-1001 pump, a K-2001 UV detector operating at $254 \mathrm{~nm}, 20$ $\mu l$ sample injector (Rheodyne, Cocati, CA, USA) and a stainless-steel column packed with Hypersil ODS (200 mm length; $4.6 \mathrm{~mm}$ in diameter and $5 \mu \mathrm{m}$ thickness of granules). The flow rate was $0.5 \mathrm{ml} / \mathrm{min}$. The isocratic mobile phase consisted of methanol-water $(25: 75 \mathrm{v} / \mathrm{v})$ with $1 \%$ $\mathrm{v} / \mathrm{v}$ acetic acid. The mobile phase for identifying chlorogenic acid fraction was: water: ethyl acetate: acetic acid (95.6:4.1:0.3 v/v/v) (Shahrzad and Bitsch 1996). This acid was detected at 280 and $320 \mathrm{~nm}$. The determination of the contents of investigated compounds was made on the basis of linear dependence between peak areas and concentration. In this case the external standard method was used. The chromatograms were recorded and the amounts of phenolic acids were determined with EUROCHROM 2000 software. The results of RP-HPLC analyses are given in Table 2. The example of the HPLC chromatogram of phenolic acids from fraction $\mathrm{B}$ of the inflorescences from Hieracium pilosella is presented in Figure 2.

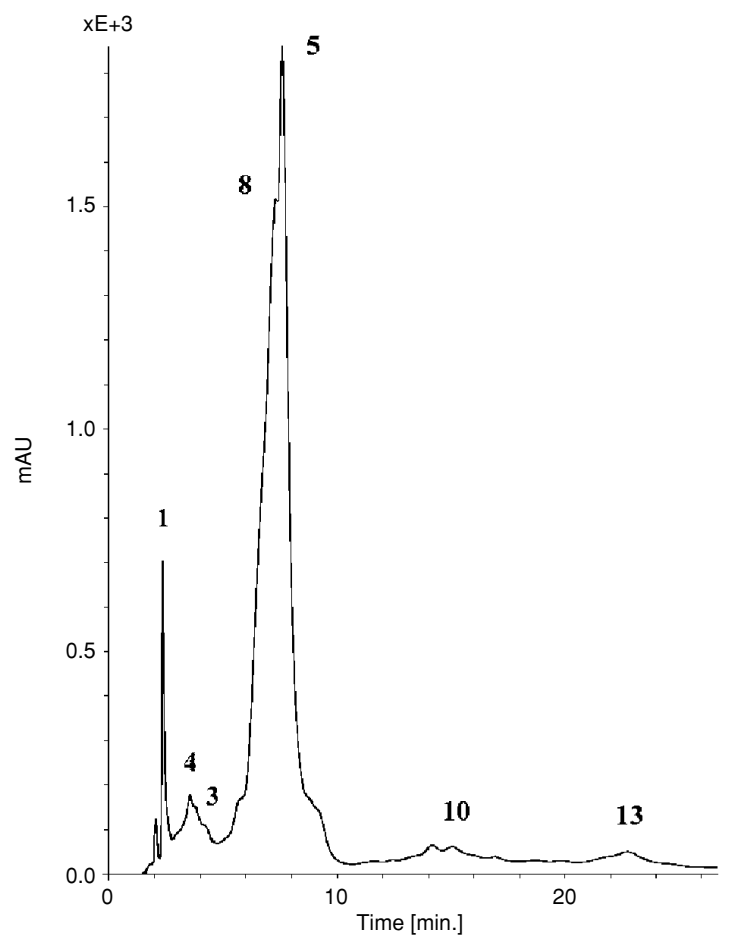

Fig. 2. The HPLC chromatogram of the bound phenolic acids fraction (fraction B) from inflorescences of Hieracium pilosella. The identification numbers of peaks refer to compounds listed in Table 2.

\section{RESULTS AND DISCUSSION}

The fractions of the free and bound phenolic acids, as well as chlorogenic acid (fractions A, B, C respectively), prepared from water-methanol extracts of inflorescences and rhizomes with roots of $H$. pilosella, were analysed by chromatographic methods like 2D-TLC and RP-HPLC. A very rich composition of phenolic acids in the plant ma-

TABLE 2. The contents of major phenolic acids in Hieracium pilosella $\mathrm{L}$.

\begin{tabular}{|c|c|c|c|c|c|c|}
\hline \multirow{3}{*}{ Phenolic acids } & \multicolumn{6}{|c|}{ The contents of phenolic acids in $\mathrm{mg} / 100 \mathrm{~g}$ (dry weight) } \\
\hline & \multicolumn{3}{|c|}{ Rhizomes with roots } & \multicolumn{3}{|c|}{ Inflorescences } \\
\hline & $\begin{array}{l}\text { Free } \\
\text { (A) }\end{array}$ & $\begin{array}{l}\text { Bound } \\
\text { (B) }\end{array}$ & $\begin{array}{c}\text { Total } \\
(\mathrm{A}+\mathrm{B})\end{array}$ & $\begin{array}{l}\text { Free } \\
\text { (A) }\end{array}$ & $\begin{array}{l}\text { Bound } \\
\text { (B) }\end{array}$ & $\begin{array}{c}\text { Total } \\
(\mathrm{A}+\mathrm{B})\end{array}$ \\
\hline gallic & 0.72 & 10.48 & 11.20 & 1.06 & 9.52 & 10.58 \\
\hline p-hydroxybenzoic & 0.04 & 17.45 & 17.49 & 0.17 & 8.12 & 8.29 \\
\hline protocatechuic & - & - & - & 0.82 & 0.72 & 1.54 \\
\hline homoprotocatechuic & - & 2.16 & 2.16 & 0.34 & 16.59 & 16.93 \\
\hline vanillic & $\operatorname{tr}$ & 29.59 & 29.59 & $\operatorname{tr}$ & $\operatorname{tr}$ & $\operatorname{tr}$ \\
\hline p-coumaric & - & - & - & $\mathrm{tr}$ & 2.50 & 2.50 \\
\hline ferulic & - & - & - & $\operatorname{tr}$ & 2.31 & 2.31 \\
\hline caffeic & $\operatorname{tr}$ & 139.50 & 139.50 & 0.01 & 53.91 & 53.92 \\
\hline chlorogenic & - & - & 0.59 & - & - & 5.43 \\
\hline
\end{tabular}

Explanations:

A - free phenolic acids fraction; B - bound phenolic acids fraction (liberated after acidic and alkaline hydrolysis); $\operatorname{tr}-\operatorname{trace}$ quantities 
terials was observed. The rhizomes with roots and the inflorescences of the investigated plant contain derivatives of benzoic, cinnamic and phenylacetic acids. Fourteen compounds were identified in total: chlorogenic, gallic, protocatechuic, homoprotocatechuic, caffeic, gentisic, p-hydroxyphenylacetic, p-hydroxybenzoic, m-hydroxybenzoic, pcoumaric, syringic, vanillic, ferulic and salicylic. They are described for the first time in investigated parts of the plant, except for caffeic and chlorogenic acids. Most of the phenolic acids occurred both in free and bound form. The $\mathrm{m}$-hydroxybenzoic acid in the inflorescences and the homoprotocatechuic in the rhizomes with roots appeared to occur in the bound form only. The inflorescences are the richest in the phenolic acids part of the plant. In the rhizomes with roots there were no protocatechuic, m-hydroxybenzoic, p-coumaric, ferulic and salicylic acids which were present in the inflorescences.

The RP-HPLC method enabled estimation of the contents of major phenolic acids in all obtained fractions. They are quite diverse and range from 0.01 up to $139.50 \mathrm{mg} / 100$ $\mathrm{g}$ of the dry material. The large increase of the quantities of acids in the fractions obtained by hydrolyses was observed. For example the amount of caffeic acid released after both alkaline and acidic hydrolyses increased from $0.01 \mathrm{mg}$ to $53.91 \mathrm{mg} / 100 \mathrm{~g}$ of dry inflorescences. One may recapitulate that the phenolic acids in the bound form, i.e. combined with sugars by glycosidic and/or ester linkage appear to occur in the plant in a much larger quantity than in a free state.

The individual acids are present in diverse proportions in the different parts of the plant, but caffeic acid is a remarkably dominating compound in the inflorescences, rhizomes with roots and also in the herb (Dombrowicz et al. 1992). The gallic acid and p-hydroxybenzoic acid are also present in significant amounts in the rhizomes with roots and the inflorescences of $\mathrm{H}$. pilosella. In the latter material homoprotocatechuic acid follows caffeic and in the rhizomes with roots vanillic is in the second place with regard to its quantitative content

Both plant materials contain chlorogenic and caffeic acids known for phytotoxicity (Makepeace 1985). What is significant, in the rhizomes and roots there is almost three times more of caffeic acid than in the inflorescences. If the investigated plant exudates these components from the roots into the soil, the growth of other plants in its neighbourhood may be inhibited or very difficult. Ferulic, syringic, p-coumaric, p-hydroxybenzoic and vanillic acids - all determined in the plant, also show a strong phytotoxic activity (Harborne 1997). These phenolic compounds can influence the invasiveness of Hieracium pilosella.

On the other hand most of the identified phenolic acids show a certain pharmacological activity. The attention should be paid especially to the acids present in larger amounts, such as caffeic, p-hydroxybenzoic, gallic and vanillic - compounds with known antimicrobial, antiphlogistic properties (Borkowski 1993a, b; Masquelier et al. 1965; Duquénois et al. 1956). These in smaller quantities but with significant anti-inflammatory activity like salicylic acid or fungicidal activity like protocatechuic acid (Negwer 1978) act synergistically and also influence therapeutic effect of Hieracium pilosella. Using this medicinal plant in treatment of the inflammations of the urinary tract and the upper parts of the respiratory tract seems to be justified.

\section{LITERATURE CITED}

BARBOUR E.K., AL SHARIF M.., SAGHERIAN V.K., HABRE A.N., TALHOUK R.S., TALHOUK S.N. 2004. Screening of selected indigenous plants of Lebanon for antimicrobial activity. J. Ethnopharmacol. 93: 1-7.

BISHOP G.F., DAVY A.J. 1994. Biological flora of the British Isles. Hieracium pilosella L. (Pilosella officinarum F. Schultz \& Schultz-Bip.). J. Ecol. 82: 195-210.

BORKOWSKI B. 1993a. Fenolokwasy i ich estry. I. Herba Pol. 39: 71-83. (in Polish)

BORKOWSKI B. 1993b. Fenolokwasy i ich estry. II Herba Pol. 39: 139-146. (in Polish with English summary)

BOWN D. 1999. Wielka encyklopedia ziół. Muza, Warszawa. (in Polish)

DOMBROWICZ E., ŚWIATEK L., KOPYCKI W. 1992. Phenolic acids in Inflorescentia Helichrysi and Herba Hieracii pilosellae. Pharmazie. 47: 469-470.

DUQUÉNOIS P., GREIB E. 1956. Les principes antibactériens de la Piloselle, Hieracium pilosella L. Ann. Pharm. Franc. 14: 685-690.

DZIDO T.H. 1993. The Horizontal DS-Chamber and its Modifications. J. Planar Chromatogr. 6: 78.

HARBORNE J.B. 1997. Ekologia biochemiczna. PWN, Warszawa. (in Polish)

IBRAHIM R.K., TOWERS G.H. 1960. Identification by chromatography of plant phenolic acids Arch. Biochem. Biophys. 87: 125.

JERZMANOWSKA Z. 1967. Substancje roślinne. Metody wyodrebniania. PWN, Warszawa. (in Polish)

KOPCEWICZ J., LEWAK S. 1998. Podstawy fizjologii roślin. PWN, Warszawa. (in Polish)

KRZACZEK T. 1984. Fenolokwasy w niektórych surowcach garbnikowych z rodziny Rosaceae. Farm. Pol. 40 (8): 475-477. (in Polish with English summary)

KUŹNIEWSKI E., AUGUSTYN-PUZIEWICZ J. 1984. Przewodnik ziołolecznictwa ludowego. PWN, Warszawa-Wrocław. (in Polish)

LINSKENS H.T. 1959. Papierchromatographie In der Botanik. Springer-Verlag, Berlin-Goettingen-Heidelberg.

MAKEPEACE W., DOBSON A.T., SCOTT D. 1985. Interference phenomena due to mouse-ear and king devil hawkweeds. $\mathrm{N}$. Z. J. Bot. 23: 79-90.

MASQUELIER J., DALNNAY D. 1965. Bactericidal action of the phenolic acids of wine. Bull. Soc. Pharm. Bord. 104: 152.

MIRALDI E., FERRI S., MOSTAGHIMI V. 2001. Botanical drugs and preparations in the traditional medicine of West Azerbaijan (Iran). J. Ethnopharmacol. 75: 77-87.

NEGWER M. 1978. Organic-chemical drugs and their synonyms. Academie-Verlag, Berlin.

RANDERATH K. 1962. Dünschicht-Chromatographie. Verlag Chemie. Weinheim.

SCHMIDTLEIN H., HERRMANN K. 1975. Quantitative analysis for phenolic acids by thin layer chromatography. J. Chromatogr. 115: 123-128.

SHAHRZAD S., BITSCH I. 1996. Determination of some pharmacologically active phenolic acids in juices by high-performance liquid chromatography. J. Chromatogr. 741: 223-231.

SMOLARZ H.D., WAKSMUNDZKA-HAJNOS M. 1993. Twodimensional TLC of phenolic acids on cellulose. J. Planar Chromatogr. 6: 278.

ŚWIĄTEK L., DOMBROWICZ E. 1984. Kwasy fenolowe w surowcach goryczowych. Cz. I. Badanie ziela piołunu i korzenia goryczki. Farm. Pol. 40: 729-732. (in Polish with English summary)

ZIDORN C., GOTTSCHLICH G., STUPPNER H. 2002. Chemosystematic investigations on phenolics from flowerheads of Central European taxa of Hieracium sensu lato (Asteraceae). Plant Syst. Evol. 231: 39-58. 